2016

\title{
Caddo Ceramic Vessels from the Joseph Fabion (41SY24) and S. H. Latham (41SY25) Sites in Shelby County, Texas
}

Timothy K. Perttula

Heritage Research Center, Stephen F. Austin State University

Follow this and additional works at: https://scholarworks.sfasu.edu/ita

Part of the American Material Culture Commons, Archaeological Anthropology Commons, Environmental Studies Commons, Other American Studies Commons, Other Arts and Humanities Commons, Other History of Art, Architecture, and Archaeology Commons, and the United States History Commons

Tell us how this article helped you.

This Article is brought to you for free and open access by the Center for Regional Heritage Research at SFA ScholarWorks. It has been accepted for inclusion in Index of Texas Archaeology: Open Access Gray Literature from the Lone Star State by an authorized editor of SFA ScholarWorks. For more information, please contact cdsscholarworks@sfasu.edu. 


\section{Caddo Ceramic Vessels from the Joseph Fabion (41SY24) and S. H. Latham (41SY25) Sites in Shelby County, Texas}

\section{Creative Commons License}

\section{(c) (1) (8)}

This work is licensed under a Creative Commons Attribution-NonCommercial 4.0 International License 


\title{
Caddo Ceramic Vessels from the Joseph Fabion (41SY24) and S. H. Latham (41SY25) Sites in Shelby County, Texas
}

\author{
Timothy K. Perttula
}

\section{INTRODUCTION}

There are ancestral Caddo vessels in the collections of the Texas Archeological Research Laboratory at the University of Texas from the Joseph Fabion (41SY24, n=4 vessels) and S. H. Latham (41SY25, n=3) sites in Shelby County, Texas. Those vessels from the Joseph Fabion site were exposed along the bank of a county road some time prior to October 1930, while those from the S. H. Latham site were exposed by 1920 s flooding and collected by the landowner.

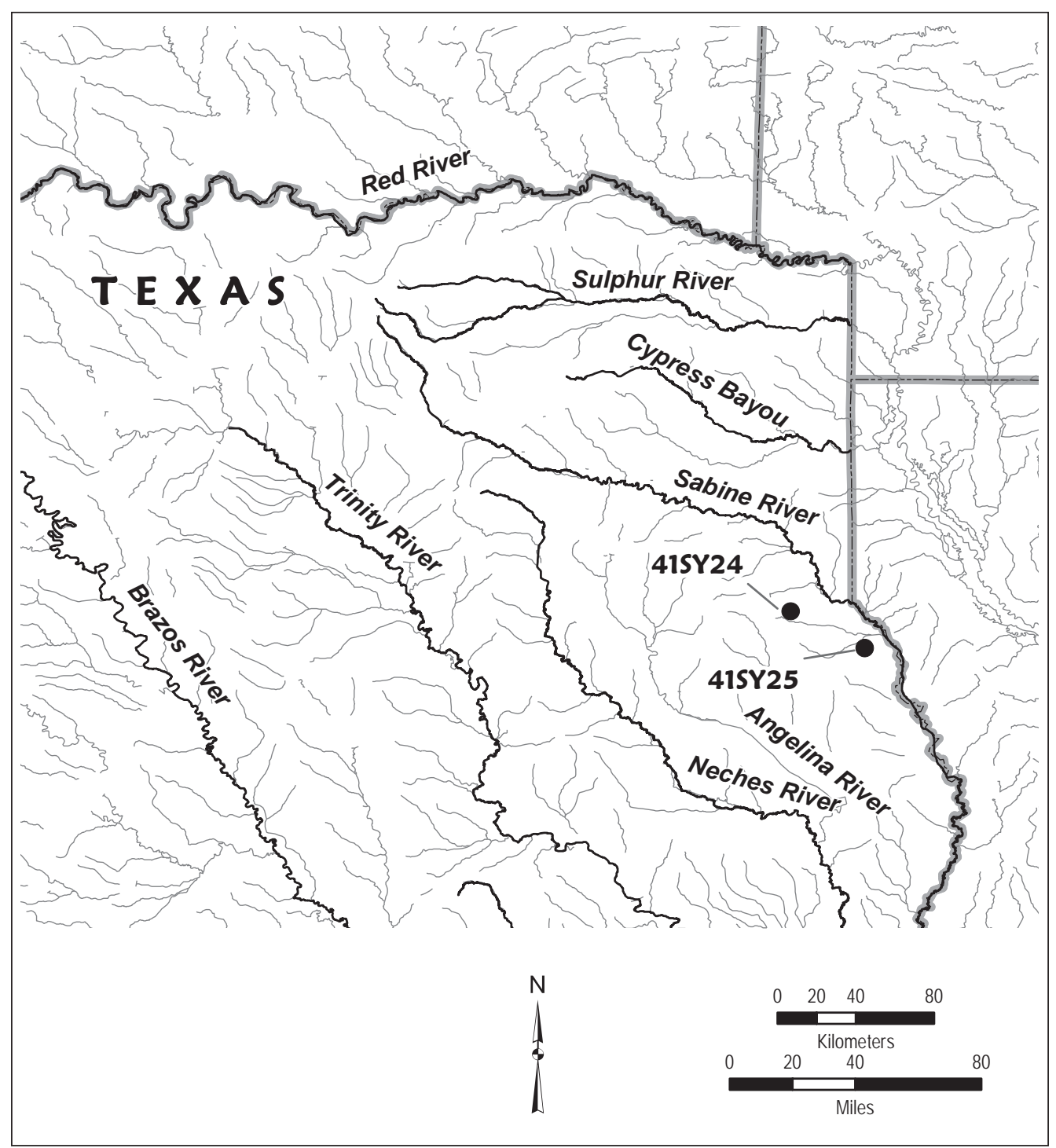

Figure 1. Location of the Joseph Fabion (41SY24) and S. H. Latham (41SY25) sites in East Texas. 


\section{Documentation of Vessels from the Joseph Fabion Site (41SY24)}

The Joseph Fabion site is located along a northward-flowing tributary to Flat Fork Creek in the Sabine River basin in East Texas. The four vessels from the Joseph Fabion site in the TARL collections were donated to the University of Texas by a Mr. Frank Bussey in October 1930.

SITE NAME OR SITE NUMBER: Joseph Fabion

VESSEL NO.: 1

VESSEL FORM: Bowl with a scalloped/cut lip

NON-PLASTICS AND PASTE: grog

RIM AND LIP FORM: Direct rim and rounded lip

CORE COLOR: $\mathrm{F}$ (fired in a reducing environment and cooled in the open air)

INTERIOR SURFACE COLOR: dark reddish-brown; fire clouds on the rim and body

EXTERIOR SURFACE COLOR: dark reddish-brown; fire clouds on the rim, body, and base

WALL THICKNESS (IN MM): rim, $6.3 \mathrm{~mm}$

INTERIOR SURFACE TREATMENT: smoothed

EXTERIOR SURFACE TREATMENT: smoothed

HEIGHT (IN CM): 4.4

ORIFICE DIAMETER (IN CM): 10.2

DIAMETER AT BOTTOM OF RIM OR NECK (IN CM): N/A

BASE DIAMETER (IN CM) AND SHAPE OF BASE: 5.1; circular and rounded

ESTIMATED VOLUME (IN LITERS): 0.2

DECORATION (INCLUDING MOTIF AND ELEMENTS WHEN APPARENT): There is a single horizontal engraved line beneath the vessel lip, as well as four curvilinear or rectangular panels that have ovoid-shaped and one or two circular engraved zones filled with cross-hatched lines (Figure 2).

PIGMENT USE AND LOCATION ON VESSEL: white clay pigment in the engraved lines

TYPE AND VARIETY (IF KNOWN): Unidentified fine ware

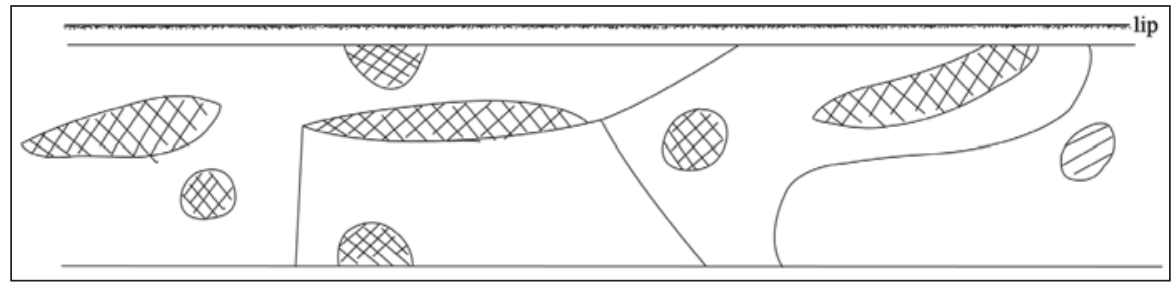

Figure 2. Decorative elements on an engraved bowl from the Joseph Fabion site (41SY24). 
SITE NAME OR SITE NUMBER: Joseph Fabion

VESSEL NO.: 3

VESSEL FORM: Bottle

NON-PLASTICS AND PASTE: grog

RIM AND LIP FORM: Direct rim and rounded lip

CORE COLOR: $\mathrm{G}$ (fired in a reducing environment and cooled in the open air)

INTERIOR SURFACE COLOR: dark grayish-brown

EXTERIOR SURFACE COLOR: dark yellowish-brown; fire clouds on the rim, body, and base

WALL THICKNESS (IN MM): rim, $5.6 \mathrm{~mm}$

INTERIOR SURFACE TREATMENT: none

EXTERIOR SURFACE TREATMENT: smoothed

HEIGHT (IN CM): 13.3

ORIFICE DIAMETER

(IN CM): 2.7

DIAMETER AT BOTTOM

OF RIM OR NECK (IN CM):

3.9; maximum body diameter is $8.4 \mathrm{~cm}$

BASE DIAMETER (IN CM) AND SHAPE OF BASE: 4.4; circular and flat

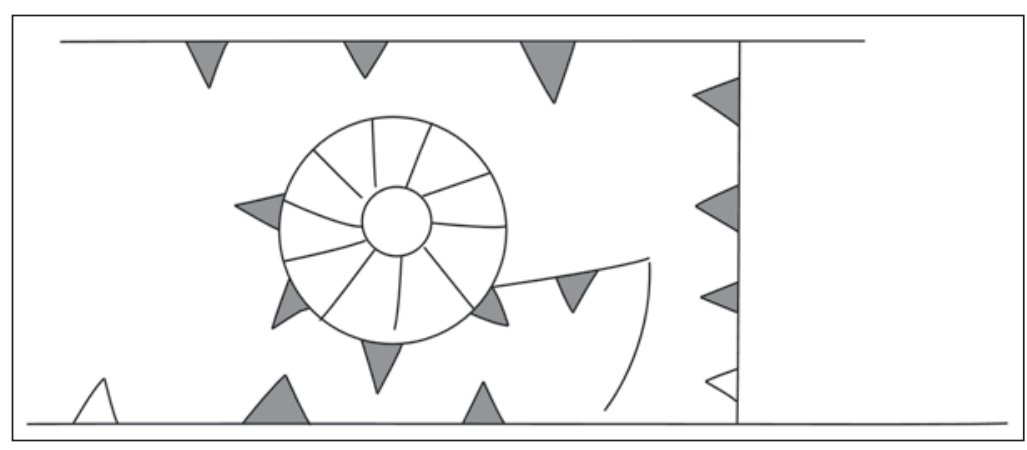

Figure 3. Decorative elements on an engraved bottle from the Joseph Fabion site.

ESTIMATED VOLUME (IN LITERS): 0.2

DECORATION (INCLUDING MOTIFAND ELEMENTS WHENAPPARENT): The vessel body is divided into four rectangular panels by vertical engraved lines with excised and open pendant triangles. The top and bottom of the panels also have excised pendant triangles either pointing towards the vessel base or the vessel neck. In the panels are a single engraved circle that has an inner open circle; the two circles are connected by a series of vertical or diagonal engraved lines. There are excised pendant triangles around half of the circumference of the larger circle element, along with an attached diagonal to vertical engraved line with a single excised pendant triangle (Figure 3).

PIGMENT USE AND LOCATION ON VESSEL: none

TYPE AND VARIETY (IF KNOWN): Unidentified fine ware 
SITE NAME OR SITE NUMBER: Joseph Fabion

VESSEL NO.: 10

VESSEL FORM: Bowl or Cup

NON-PLASTICS AND PASTE: bone

RIM AND LIP FORM: Direct rim and rounded lip

CORE COLOR: B (fired and cooled in a reducing environment)

INTERIOR SURFACE COLOR: very dark grayish-brown

EXTERIOR SURFACE COLOR: very dark grayish-brown; fire clouds on the rim and body

WALL THICKNESS (IN MM): rim, $5.3 \mathrm{~mm}$

INTERIOR SURFACE TREATMENT: none

EXTERIOR SURFACE TREATMENT: none

HEIGHT (IN CM): 7.6

ORIFICE DIAMETER (IN CM): 7.0

DIAMETER AT BOTTOM OF RIM OR NECK (IN CM): N/A

BASE DIAMETER (IN CM) AND SHAPE OF BASE: 5.1; circular and flat

ESTIMATED VOLUME (IN LITERS): 0.2

DECORATION (INCLUDING MOTIF AND ELEMENTS WHEN APPARENT): Plain

PIGMENT USE AND LOCATION ON VESSEL: none

TYPE AND VARIETY (IF KNOWN): Unidentified plain ware 
SITE NAME OR SITE NUMBER: Joseph Fabion

VESSEL NO.: 12

VESSEL FORM: Jar

NON-PLASTICS AND PASTE: grog

RIM AND LIP FORM: Direct rim and rounded lip

CORE COLOR: B (fired and cooled in a reducing environment)

INTERIOR SURFACE COLOR: dark grayish-brown

EXTERIOR SURFACE COLOR: dark grayish-brown

WALL THICKNESS (IN MM): rim, $5.2 \mathrm{~mm}$

INTERIOR SURFACE TREATMENT: smoothed

EXTERIOR SURFACE TREATMENT: smoothed on the body

HEIGHT (IN CM): 13.4

ORIFICE DIAMETER (IN CM): 12.7

DIAMETER AT BOTTOM OF RIM OR NECK (IN CM): 12.5

BASE DIAMETER (IN CM) AND SHAPE OF BASE: 8.9; circular and flat

ESTIMATED VOLUME (IN LITERS): 1.0

DECORATION (INCLUDING MOTIF AND ELEMENTS WHEN APPARENT): The rim is decorated with six curvilinear and semi-circular incised zones filled with tool punctations (Figure 4).

PIGMENT USE AND LOCATION ON VESSEL: none

TYPE AND VARIETY (IF KNOWN): Pineland Punctated-Incised (Jelks 1965)

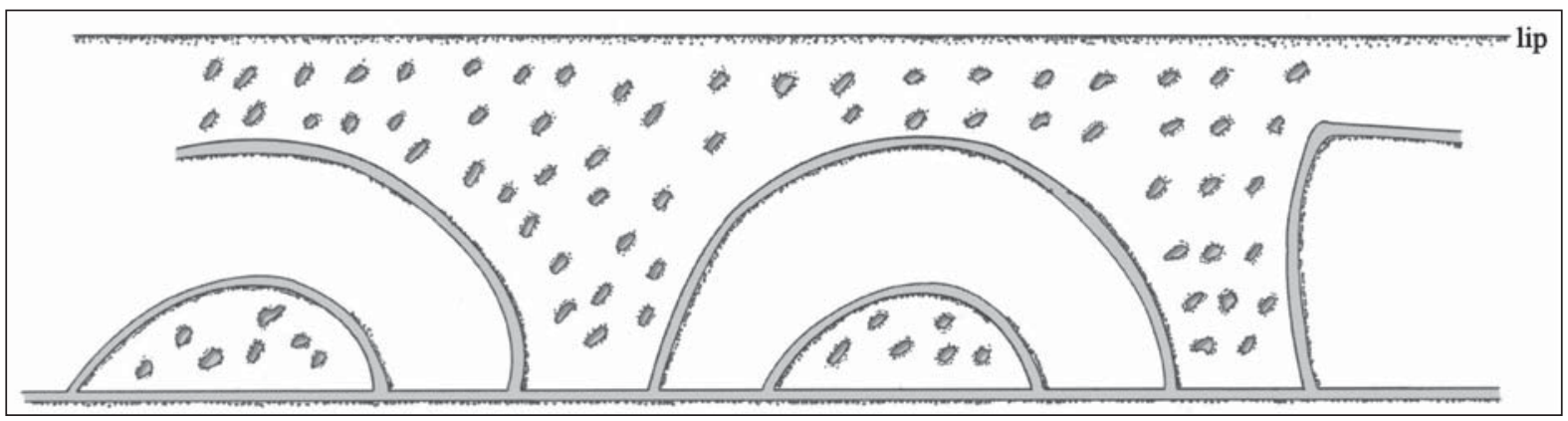

Figure 4. Decorative elements on Pineland Punctated-Incised jar from the Joseph Fabion site. 


\section{Documentation of Vessels from the S. H. Latham Site (41SY25)}

The S, H. Latham site is on Bayou Siepe in the Sabine River basin, about $16 \mathrm{~km}$ from its junction with the Sabine River. The three ceramic vessels in the TARL collections from the S. H. Latham site were purchased by UT from the landowner in May 1931. The vessels had been previously exposed by stream erosion and collected by the landowner in the 1920s, along with human skeletal remains.

SITE NAME OR SITE NUMBER: S. H. Latham

VESSEL NO.: 1

VESSEL FORM: Jar

NON-PLASTICS AND PASTE: grog and bone

RIM AND LIP FORM: Missing

CORE COLOR: F (fired in a reducing environment and cooled in the open air)

INTERIOR SURFACE COLOR: reddish-brown

EXTERIOR SURFACE COLOR: reddish-brown; fire clouds on the body and base

WALL THICKNESS (IN MM): lower rim, $5.6 \mathrm{~mm}$

INTERIOR SURFACE TREATMENT: none

EXTERIOR SURFACE TREATMENT: smoothed on the body

HEIGHT (IN CM): 6.4+

ORIFICE DIAMETER (IN CM): 5.1 (lower rim)

DIAMETER AT BOTTOM OF RIM OR NECK (IN CM): 5.3

BASE DIAMETER (IN CM) AND SHAPE OF BASE: 5.1; circular and rounded

ESTIMATED VOLUME (IN LITERS): 0.2+

DECORATION (INCLUDING MOTIF AND ELEMENTS WHEN APPARENT): Plain

PIGMENT USE AND LOCATION ON VESSEL: none

TYPE AND VARIETY (IF KNOWN): Unidentified plain ware 
SITE NAME OR SITE NUMBER: S. H. Latham

VESSEL NO.: 2

VESSEL FORM: Bottle with a carinated body

NON-PLASTICS AND PASTE: grog

RIM AND LIP FORM: Direct rim and rounded lip

CORE COLOR: $\mathrm{G}$ (fired in a reducing environment and cooled in the open air)

INTERIOR SURFACE COLOR: dark grayish-brown

EXTERIOR SURFACE COLOR: yellowish-brown; fire clouds on the rim and body

WALL THICKNESS

(IN MM): rim, $4.6 \mathrm{~mm}$

INTERIOR SURFACE

TREATMENT: none

EXTERIOR SURFACE

TREATMENT: smoothed

HEIGHT (IN CM): 13.3

ORIFICE DIAMETER

(IN CM): 5.9

DIAMETER AT BOTTOM

OF RIM OR NECK

(IN CM):5.3; maximum

body diameter is $10.8 \mathrm{~cm}$.

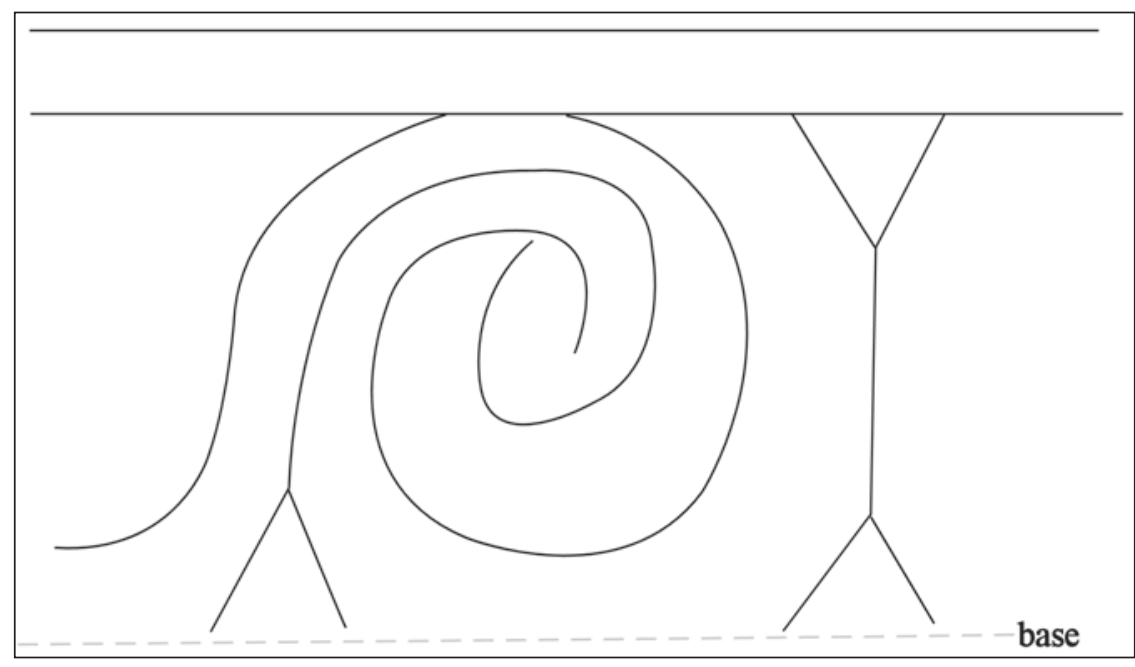

Figure 5. Decorative elements on an engraved bottle from the S. H. Latham site (41SY25).

BASE DIAMETER (IN CM) AND SHAPE OF BASE: 4.8; circular and flat

ESTIMATED VOLUME (IN LITERS): 0.2

DECORATION (INCLUDING MOTIF AND ELEMENTS WHEN APPARENT): The upper part of the vessel body has two horizontal engraved lines. The remainder of the vessel body is divided into four panels by vertical brackets with upper and lower open triangle elements. The panels have curvilinear and hooked arm engraved elements that begin at the apex of an open pendant triangle (Figure 5).

PIGMENT USE AND LOCATION ON VESSEL: none

TYPE AND VARIETY (IF KNOWN): cf. Wilder Engraved 
SITE NAME OR SITE NUMBER: S. H. Latham

VESSEL NO.: 3

VESSEL FORM: Bottle with a short neck

NON-PLASTICS AND PASTE: grog

RIM AND LIP FORM: Everted rim and a rounded lip

CORE COLOR: F (fired in a reducing environment and cooled in the open air)

INTERIOR SURFACE COLOR: brown

EXTERIOR SURFACE COLOR: brown; fire clouds on the rim, body, and base

WALL THICKNESS (IN MM):

rim, $6.7 \mathrm{~mm}$

INTERIOR SURFACE

TREATMENT: burnished

on the neck

EXTERIOR SURFACE

TREATMENT: burnished

HEIGHT (IN CM): 12.7

ORIFICE DIAMETER

(IN CM): 6.7

DIAMETER AT BOTTOM

OF RIM OR NECK (IN CM):

6.2; maximum body diameter

is $11.7 \mathrm{~cm}$.

BASE DIAMETER (IN CM)

AND SHAPE OF BASE:

7.0; circular and flat

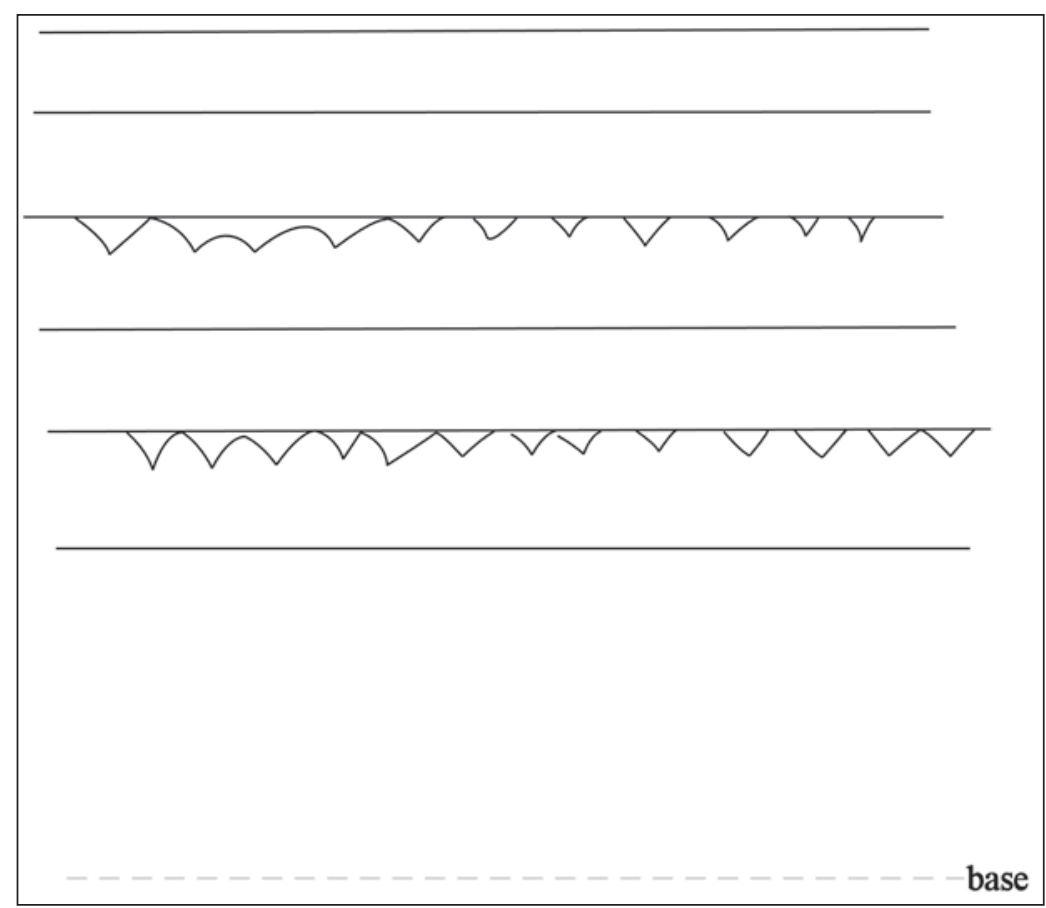

Figure 6. Decorative elements on an engraved bottle from the S. H. Latham site (41SY25).

ESTIMATED VOLUME (IN LITERS): 0.4

DECORATION (INCLUDING MOTIFAND ELEMENTS WHENAPPARENT): The upper part of the vessel body has six equally-spaced horizontal engraved lines. The third and fifth horizontal engraved lines have a series of 23 or 29 curvilinear and triangular engraved elements pendant from these horizontal lines (Figure 6).

PIGMENT USE AND LOCATION ON VESSEL: none

TYPE AND VARIETY (IF KNOWN): Unidentified fine ware 


\section{SUMMARY AND CONCLUSIONS}

The four vessels from the Joseph Fabion site are both grog-tempered $(n=3)$ and bone-tempered $(n=1)$. The bone-tempered vessel is a small bowl or small jar, while the grog-tempered vessels include an engraved bowl and an engraved bottle of uncertain type, along with a Pineland Punctated-Incised jar (see Jelks 1965), although there are stylistic resemblances to the engraved vessels from the Middle Caddo period Washington Square Mound site (41NA49) in the Angelina River basin (Hart 2014; Hart and Perttula 2010; Perttula et al. 2010). The proportion of brushed sherds ( 42.5 percent) in the small assemblage of decorated sherds from the site also suggest its principal occupation was by Caddo peoples in the Middle Caddo period (ca. A.D. 1200-1400).

In the case of the vessels from the S. H. Latham site, one is a plain grog- and bone-tempered jar, while the other two are grog-tempered engraved bottles. The first bottle has decorative elements very reminiscent of Wilder Engraved, a Late Caddo period type found on sites in the Big Cypress and Sabine River basins, including sites at Toledo Bend Reservoir (Perttula and Walters 2015), while the second has horizontal

engraved lines on the vessel body as well as two sets of scalloped engraved elements pendant from two of the horizontal engraved lines.

\section{REFERENCES CITED}

Hart, J. P.

2014 An Analysis of the Aboriginal Ceramics from the Washington Square Mound Site, Nacogdoches County, Texas. Stephen F. Austin State University Press, Nacogdoches.

Hart, J. P. and T. K. Perttula

2010 The Washington Square Mound Site and a Southeastern Ceremonial Complex Style Zone among the Caddo of Northeastern Texas. Midcontinental Journal of Archaeology 35(2):199-228.

Jelks, E. B.

1965 The Archeology of McGee Bend Reservoir, Texas. Ph.D. dissertation, Department of Anthropology, The University of Texas at Austin.

Perttula, T. K. and M. Walters

2015 Woodland and Caddo Period Sites at Toledo Bend Reservoir, Northwest Louisiana and East Texas. Journal of Northeast Texas Archaeology 56:19-124.

Perttula, T. K., M. Walters, B. Nelson, B. Gonzalez, and R. Cast, with a contribution by R. G. Franciscus

2010 Documentation of Associated and Unassociated Caddo Funerary Objects in the Stephen F. Austin State University Collections, Nacogdoches, Texas. Stephen F. Austin State University Press, Nacogdoches. 